\title{
Highly efficient base-free aerobic oxidation of alcohols over gold nanoparticles supported on $\mathrm{ZnO}-\mathrm{CuO}$ mixed oxides
}

\author{
Wei Wang a,b, Yan Xie a,\#, Shaohua Zhang a , Xing Liu a, Liyun Zhang c, Bingsen Zhang c, \\ Masatake Haruta d, Jiahui Huang a,* \\ a Gold Catalysis Research Center, State Key Laboratory of Catalysis, Dalian Institute of Chemical Physics, Chinese Academy of Sciences, Dalian 116023, \\ Liaoning, China \\ b University of Chinese Academy of Sciences, Beijing 100049, China \\ c Shenyang National Laboratory for Materials Science, Institute of Metal Research, Chinese Academy of Sciences, Shenyang 110016, Liaoning, China \\ d Research Center for Gold Chemistry, Department of Applied Chemistry, Graduate School of Urban Environmental Sciences, Tokyo Metropolitan \\ University, Hachioji, Tokyo 192-0379, Japan
}

\section{A R T I C L E I N F O}

\section{Article history:}

Received 29 April 2019

Accepted 23 June 2019

Published 5 December 2019

\section{Keywords:}

Gold catalysis

ZnO-CuO mixed oxides

Alcohols

Aerobic oxidation

Base-free reaction

\begin{abstract}
A B S T R A C T
The design and preparation of suitable supports are of great importance for gold catalysts to attain excellent catalytic performance for alcohol oxidation. In this work, we found that $\mathrm{ZnO}-\mathrm{CuO}$ mixed oxides supported gold catalysts showed much better catalytic activity for base-free aerobic oxidation of benzyl alcohol than $\mathrm{Au} / \mathrm{ZnO}$ and $\mathrm{Au} / \mathrm{CuO}$ catalysts, and among them $\mathrm{Au} / \mathrm{Zn}_{0.7} \mathrm{Cu}_{0.3} \mathrm{O}$ displayed the best catalytic performance. In addition, the $\mathrm{Au} / \mathrm{Zn}_{0.7} \mathrm{Cu}_{0.3} \mathrm{O}$ catalyst could selectively catalyze the aerobic oxidation of a wide range of alcohols to produce the corresponding carbonyl compounds with high yields under mild conditions without base. Further characterizations indicated that the outstanding catalytic performance of $\mathrm{Au} / \mathrm{Zn}_{0.7} \mathrm{Cu}_{0.3} \mathrm{O}$ was correlated with the small size of $\mathrm{Au}$ nanoparticles (NPs), good low-temperature reducibility, high concentration of surface oxygen species, and collaborative interaction between Au NPs and mixed oxide.
\end{abstract}

(C) 2019, Dalian Institute of Chemical Physics, Chinese Academy of Sciences. Published by Elsevier B.V. All rights reserved.

\section{Introduction}

Aldehydes and ketones are pivotal intermediates and widely used in the manufacture of fine chemicals. The selective oxidation of alcohols to the corresponding aldehydes and ketones is deemed as one of the most crucial transformations in the chemical industry. Traditionally, the selective oxidation of alcohol is normally carried out using stoichiometric oxidants, bringing about a lot of environment pollution. Currently, to realize the efficient selective oxidation of alcohol using molec- ular oxygen instead of toxic oxidants is more desirable and has attracted great research efforts [1-6].

Inspired by pioneering work of Haruta et al. [7] and Hutchings et al. [8], the catalytic performance and reaction mechanism of gold catalysts have been comprehensively studied for more than 30 years. Gold catalysts have displayed extraordinarily high catalytic performance for a great deal of reactions [9-13]. As reported in the literature, the catalytic activity of gold catalysts is highly related to the size of gold [14], the type of support [15], and the interaction between gold and support

\footnotetext{
* Corresponding author. Tel: +86-411-82463012; Fax: +86-411-82463009; E-mail: jiahuihuang@dicp.ac.cn

\# Corresponding author. Tel: +86-411-82463017; Fax: +86-411-82463009; E-mail: yanxie@dicp.ac.cn

This work was supported by the National Natural Science Foundation of China (21606219), and the "Transformational Technologies for Clean Energy and Demonstration", Strategic Priority Research Program of the Chinese Academy of Sciences (XDA21030900).

DOI: S1872-2067(19)63429-7 | http://www.sciencedirect.com/science/journal/18722067 | Chin. J. Catal., Vol. 40, No. 12, December 2019
} 
[16]. In the aerobic oxidation of alcohols, gold catalysts have excited wide research interest because of their special catalytic properties [17-20]. Baiker et al. [21] reported that for the aerobic oxidation of alcohol, the activity of $\mathrm{Cu}-\mathrm{Mg}$-Al mixed oxide-supported gold NPs was correlated with the make-up of the support, with $\mathrm{Au} / \mathrm{Cu}_{5} \mathrm{Mg}_{1} \mathrm{Al}_{2} \mathrm{O}_{x}$ exhibiting the best catalytic performance. Cao et al. [22] reported that gold NPs supported on Ga-Al mixed oxides showed high catalytic activity for aerobic oxidation of alcohols under mild conditions without base and $\mathrm{Au} / \mathrm{Ga}_{3} \mathrm{Al}_{3} \mathrm{O}_{9}$ exhibited the best catalytic performance. Kaneda et al. [23] found that the Au/HT catalyst (HT: hydrotalcite) displayed excellent catalytic performance for the aerobic oxidation of various alcohols, giving high yields of the corresponding carbonyl compounds under mild conditions. Li et al. [24] reported that the catalytic performance for aerobic oxidation of alcohols over Au/HT could be enhanced by adding transition metal cations to HT, in which $\mathrm{Au} / \mathrm{Cr}-\mathrm{HT}$ achieved the highest catalytic performance. Albadi et al. [25] reported that the relatively large Au NPs with mean size of $5.9 \mathrm{~nm}$ supported on $\mathrm{ZnO}-\mathrm{CuO}$ mixed oxide showed high catalytic activity for aerobic oxidation of alcohols with base.

As described in previous work, the combination of gold NPs with a suitable support may fabricate highly efficient gold catalysts for aerobic oxidation of alcohols under mild conditions. In this work, a series of $\mathrm{ZnO}-\mathrm{CuO}$ mixed oxides were prepared by a co-precipitation method and then used to support gold NPs by a deposition-precipitation method. In the base-free aerobic oxidation of benzyl alcohol, ZnO-CuO mixed oxide-supported gold catalysts showed much better catalytic activity than the $\mathrm{Au} / \mathrm{ZnO}$ and $\mathrm{Au} / \mathrm{CuO}$ catalysts. In particular, the $\mathrm{Au} / \mathrm{Zn}_{0.7} \mathrm{Cu}_{0.3 \mathrm{O}}$ catalyst not only displayed the best catalytic performance for the benzyl alcohol oxidation, but also showed remarkably high catalytic activity for the aerobic oxidation of a wide range of alcohols under mild conditions.

\section{Experimental}

\subsection{Materials}

$\mathrm{Zn}\left(\mathrm{NO}_{3}\right)_{2} \cdot 6 \mathrm{H}_{2} \mathrm{O}$ (A.R.), $\mathrm{Cu}\left(\mathrm{NO}_{3}\right)_{2} \cdot 3 \mathrm{H}_{2} \mathrm{O}$ (A.R.), $\mathrm{Na}_{2} \mathrm{CO}_{3}$ (A.R.), $\mathrm{NaOH}$ (A.R.), and toluene (A.R.) were purchased from Sinopharm Chemical Reagent Co., Ltd. $\mathrm{HAuCl}_{4} \cdot 3 \mathrm{H}_{2} \mathrm{O}$ (98\%) was brought from Accela. Benzyl alcohol (99\%) was purchased from Alfa Aesar. 1-Phenylethanol (99\%) and $\alpha$-cyclopropylbenzyl alcohol (99\%) were supplied by Sigma-Aldrich. 4-Methylbenzyl alcohol (98\%), cinnamyl alcohol (98\%), benzhydrol (98\%), 4-isopropylbenzyl alcohol (97\%), and nonane (99\%) were obtained from Acros. 1-Octanol (99\%) was purchased from Tci. All reagents were used without further purification.

\subsection{Catalyst preparation}

ZnO-CuO mixed oxides were prepared by a co-precipitation method. Taking the preparation of $\mathrm{Zn}_{0.7} \mathrm{Cu}_{0.3} \mathrm{O}$ as an example, an aqueous solution $(600 \mathrm{~mL})$ containing $\mathrm{Zn}\left(\mathrm{NO}_{3}\right)_{2} \cdot 6 \mathrm{H}_{2} \mathrm{O}$ $(12.50 \mathrm{~g})$ and $\mathrm{Cu}\left(\mathrm{NO}_{3}\right)_{2} \cdot 3 \mathrm{H}_{2} \mathrm{O}(4.35 \mathrm{~g})$ was heated to $70{ }^{\circ} \mathrm{C}$ and then poured into an aqueous solution of $0.1 \mathrm{~mol} / \mathrm{L} \mathrm{Na}_{2} \mathrm{CO}_{3}(720$ $\mathrm{mL}, 1.2$ times of the stoichiometric amount), which was heated at $70{ }^{\circ} \mathrm{C}$ under vigorous stirring. Then the suspension was further aged at $70{ }^{\circ} \mathrm{C}$ for $1 \mathrm{~h}$. The precipitate was filtrated and washed carefully with deionized water. The solid obtained was dried at $120{ }^{\circ} \mathrm{C}$ overnight and calcined in air at $500{ }^{\circ} \mathrm{C}$ for $4 \mathrm{~h}$. For comparison, pure $\mathrm{ZnO}$ and $\mathrm{CuO}$ were synthesized via a precipitation method. Taking the preparation of $\mathrm{ZnO}$ as an example, an aqueous solution $(600 \mathrm{~mL})$ of $0.1 \mathrm{~mol} / \mathrm{L} \mathrm{Zn}\left(\mathrm{NO}_{3}\right)_{2}$ was heated to $70{ }^{\circ} \mathrm{C}$ and then poured into an aqueous solution of $0.1 \mathrm{~mol} / \mathrm{L} \mathrm{Na}_{2} \mathrm{CO}_{3}(720 \mathrm{~mL}, 1.2$ times of the stoichiometric amount), which was heated at $70{ }^{\circ} \mathrm{C}$ under vigorous stirring. Then the suspension was further stirred at $70^{\circ} \mathrm{C}$ for $1 \mathrm{~h}$. The precursor was treated in a similar way to that for co-precipitation.

The gold catalysts with theoretical gold loading of $4 \mathrm{wt} \%$ were prepared by a deposition-precipitation (DP) method. In a typical preparation, an aqueous solution of $2 \mathrm{mmol} / \mathrm{L} \mathrm{HAuCl}_{4}$ (200 mL) was warmed to $70{ }^{\circ} \mathrm{C}$ and the $\mathrm{pH}$ value of $\mathrm{HAuCl}_{4}$ solution was adjusted to 7.0 by gradually adding aqueous solution of $0.1 \mathrm{~mol} / \mathrm{L} \mathrm{NaOH}$ under vigorous stirring. The support material (1.92 g) was dispersed into the solution and then the $\mathrm{pH}$ was kept at 7.0 by adding aqueous $\mathrm{NaOH}$ solution. The slurry was further vigorously stirred at $70^{\circ} \mathrm{C}$ for $1 \mathrm{~h}$. Then, the solid was collected by filtration and washed with distilled water several times. The solid was dried at $120^{\circ} \mathrm{C}$ overnight and calcined at $300^{\circ} \mathrm{C}$ for $4 \mathrm{~h}$ in air.

\subsection{Catalyst characterization}

X-ray diffraction (XRD) patterns were acquired on a PANalytical Empyrean diffractometer $(40 \mathrm{kV}, 40 \mathrm{~mA})$, with $\mathrm{Cu}$ $K_{\alpha}$ radiation $(\lambda=0.1543 \mathrm{~nm})$. The BET (Brunauer-Emmett-Teller) surface areas of the samples were measured by $\mathrm{N}_{2}$ adsorption at $-196^{\circ} \mathrm{C}$ on a Micromeritics ASAP 2020 instrument. Before the analysis, the samples were evacuated at $200{ }^{\circ} \mathrm{C}$ for $6 \mathrm{~h}$ under vacuum. The actual gold loadings were determined by inductively coupled plasma optical emission spectroscopy (ICP-OES) technique conducted on a PerkinElmer 7300DV spectrometer. High-angle annular dark field scanning transmission electron microscopy (HAADF-STEM) observations were made on a FEI Tecnai G2 F20 microscope operated at $200 \mathrm{kV}$. Hydrogen temperature-programmed reduction $\left(\mathrm{H}_{2}-\mathrm{TPR}\right)$ measurements were conducted on a chemisorption instrument (ChemStar-TPx, Quantachrome). The sample (50 mg) was pretreated in Ar with a flow rate of $50 \mathrm{~mL} / \mathrm{min}$ at $250{ }^{\circ} \mathrm{C}$ for 1 h. After cooling to $40^{\circ} \mathrm{C}$, the pretreated sample was exposed to $10 \% \mathrm{H}_{2} / \mathrm{Ar}$ with a flow rate of $50 \mathrm{~mL} / \mathrm{min}$ and then heated to $800{ }^{\circ} \mathrm{C}$ at a ramp of $10{ }^{\circ} \mathrm{C} / \mathrm{min}$. The $\mathrm{H}_{2}$ consumption of the effluent was recorded on a thermal conductivity detector (TCD). Carbon dioxide temperature-programmed desorption ( $\mathrm{CO}_{2}$-TPD) was conducted on a Micromeritics Autochem 2920 II instrument. The sample (50 mg) was loaded in a U-shaped quartz microreactor and pretreated with He flow at $300{ }^{\circ} \mathrm{C}$ for $1 \mathrm{~h}$. After cooling to $50^{\circ} \mathrm{C}$, the pretreated sample was exposed to $\mathrm{CO}_{2}$ gas flow for $30 \mathrm{~min}$ and then the physically adsorbed 
$\mathrm{CO}_{2}$ was purged by He flow for $1 \mathrm{~h}$ at the same temperature. The sample was finally heated in the He flow of $30 \mathrm{~mL} / \mathrm{min}$ by raising the temperature to $800^{\circ} \mathrm{C}$ at a rate of $10^{\circ} \mathrm{C} / \mathrm{min}$ and the desorbed $\mathrm{CO}_{2}$ was detected by TCD. Oxygen temperature-programmed desorption $\left(\mathrm{O}_{2}\right.$-TPD) was performed on a Micromeritics Autochem 2920 II apparatus. The catalyst (50 mg) was pretreated in the He flow at $200{ }^{\circ} \mathrm{C}$ for $1 \mathrm{~h}$. The pretreated catalyst adsorbed $\mathrm{O}_{2}$ at $50{ }^{\circ} \mathrm{C}$ for $30 \mathrm{~min}$ and then the residual oxygen was purged with $\mathrm{He}$ flow. The catalyst was heated in He flow of $30 \mathrm{~mL} / \mathrm{min}$ from 50 to $900^{\circ} \mathrm{C}$ at a ramp of $10{ }^{\circ} \mathrm{C} / \mathrm{min}$, and the desorbed oxygen was monitored by the TCD.

\subsection{Reaction procedure}

The aerobic oxidation of alcohols was conducted in a Teflon-lined autoclave. In a typical run, the autoclave was first charged with substrate $(2 \mathrm{mmol}), n$-nonane $(1 \mathrm{mmol})$, toluene (8 mL), catalyst (Au: $0.16 \mathrm{~mol} \%$ ) and then flushed with oxygen three times. After adjusted to the desired oxygen pressure, the reactor was stirred at the desired temperature for $5 \mathrm{~h}$. After cooling, the catalyst was collected from the solution by filtration. The products were identified by a gas chromatograph-mass spectrometer (Agilent GC-MS 5977 MSD; HP-5 capillary column) and quantified by a gas chromatograph (Agilent GC 7890B; DB-1 capillary column) using $n$-nonane as an internal standard. The conversion, selectivity, and TOF were calculated as follows:

$\begin{aligned} \text { Conversion }(\%) & =\frac{\text { initial moles of substrate }- \text { moles of substrate left }}{\text { initial moles of substrate }} \\ \text { Selevtivity }(\%) & =\frac{\text { moles of product formed }}{\text { Initial moles of substrate }- \text { moles of substrate left }}\end{aligned} \times 100 \%$

\section{Results and discussion}

\subsection{Physical and chemical properties of the catalysts}

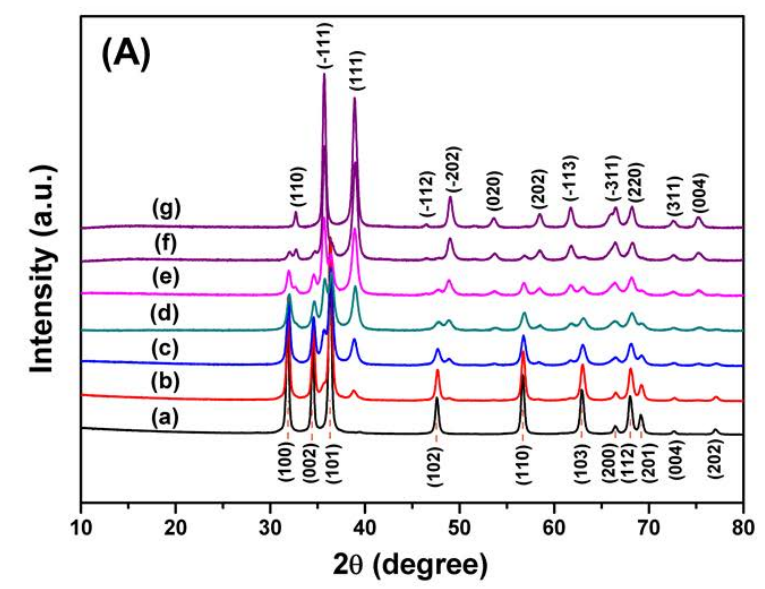

Fig. 1(A) shows the XRD patterns of support materials. For pure $\mathrm{ZnO}$ and $\mathrm{CuO}$, the diffraction peaks could be attributed to ZnO (JCPDS No. 79-2205) and CuO (JCPDS No. 65-2309), respectively. Except for the diffraction peaks of $\mathrm{ZnO}$ and $\mathrm{CuO}$, there are no other peaks observed within the XRD detection limit, implying that the mixed oxides are only comprised of $\mathrm{ZnO}$ and $\mathrm{CuO}$ phases. Upon increasing the $\mathrm{Cu} / \mathrm{Zn}$ molar ratio, the diffraction intensity of $\mathrm{CuO}$ is gradually increased, whereas the diffraction intensity of $\mathrm{ZnO}$ gradually decreased in the XRD patterns of $\mathrm{ZnO}-\mathrm{CuO}$ mixed oxides. As illustrated in Fig. 1(B), the deposition of Au NPs did not lead to an apparent impact on the crystal structure of the corresponding support except for catalysts $\mathrm{Au} / \mathrm{Zn}_{0.1} \mathrm{Cu}_{0.9} \mathrm{O}$ and $\mathrm{Au} / \mathrm{CuO}$. The diffraction intensity of $\mathrm{CuO}$ in the XRD patterns of $\mathrm{Au} / \mathrm{Zn}_{0.1} \mathrm{Cu}_{0.9} \mathrm{O}$ and $\mathrm{Au} / \mathrm{CuO}$ becomes stronger and sharper after the deposition-precipitation procedure, indicating an increase in the crystallization degree of $\mathrm{CuO}$ after re-calcination at $300{ }^{\circ} \mathrm{C}$. It should be noted that for all the gold catalysts except $\mathrm{Au} / \mathrm{Zn}_{0.7} \mathrm{Cu}_{0.3} \mathrm{O}, \mathrm{Au} / \mathrm{Zn}_{0.1} \mathrm{Cu}_{0.9} \mathrm{O}$, and $\mathrm{Au} / \mathrm{CuO}$, there were no characteristic diffraction signals of gold species, indicating that $\mathrm{Au}$ NPs were well dispersed on the surface of support [26], or the diffraction peaks of gold phase were overlapped by that of $\mathrm{CuO}$ [27]. For $\mathrm{Au} / \mathrm{Zn}_{0.7} \mathrm{Cu}_{0.3} \mathrm{O}, \mathrm{Au} / \mathrm{Zn}_{0.1} \mathrm{Cu}_{0.9} \mathrm{O}$, and $\mathrm{Au} / \mathrm{CuO}$, weak diffraction peaks at $2 \theta=44.5^{\circ}$ belonging to the $\mathrm{Au}(200)$ plane (JCPDS No. 65-8601) were detected. This result suggests that Au NPs were formed on the support surface [28].

The $\mathrm{H}_{2}$-TPR profiles of the supports are illustrated in Fig. 2(A). There is no reduction peak for $\mathrm{ZnO}$ under the experimental conditions [29]. There exists a single reduction peak centered around $225^{\circ} \mathrm{C}$ for $\mathrm{CuO}$. For the $\mathrm{ZnO}-\mathrm{CuO}$ mixed oxides, there is a major reduction peak accompanied by a shoulder reduction peak located on the left side. The reduction behavior of mixed oxides was gradually varied with the increase of copper content. It is apparent that the reduction processes of the $\mathrm{ZnO}-\mathrm{CuO}$ mixed oxides were proceeded at lower temperatures relative to pure $\mathrm{CuO}$. Since $\mathrm{ZnO}$ was not reduced under the experimental conditions, the two peaks could be ascribed to the reduction of different types of $\mathrm{CuO}$ species [30,31]. This phenomenon implies that $\mathrm{ZnO}$ improves

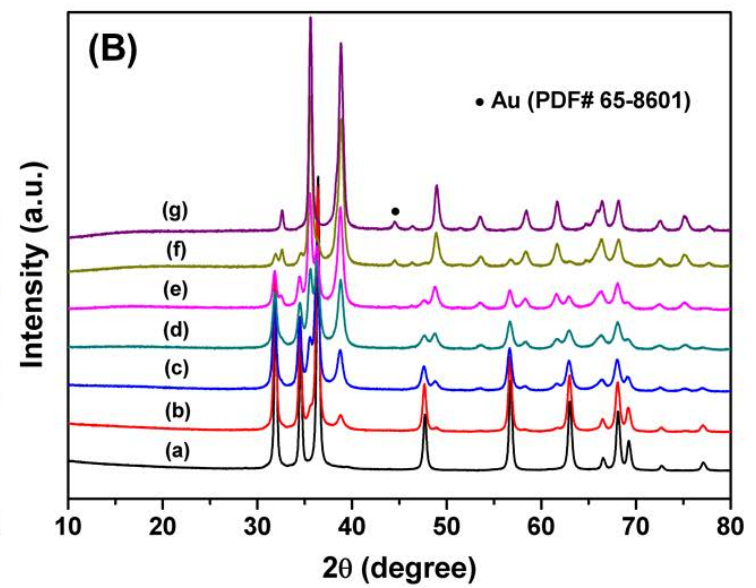

Fig. 1. (A) XRD patterns of support materials: (a) $\mathrm{ZnO}$, (b) $\mathrm{Zn}_{0.9} \mathrm{Cu}_{0.1} \mathrm{O}$, (c) $\mathrm{Zn}_{0.7} \mathrm{Cu}_{0.3} \mathrm{O}$, (d) $\mathrm{Zn}_{0.5} \mathrm{Cu}_{0.5} \mathrm{O}$, (e) $\mathrm{Zn}_{0.3} \mathrm{Cu}_{0.7} \mathrm{O}$, (f) $\mathrm{Zn} 0.1 \mathrm{Cu} 0.9 \mathrm{O}$, and (g) $\mathrm{CuO}$; (B) XRD patterns of supported gold catalysts: (a) $\mathrm{Au} / \mathrm{ZnO}$, (b) $\mathrm{Au} / \mathrm{Zn}_{0.9} \mathrm{Cu}_{0.1} \mathrm{O}$, (c) $\mathrm{Au} / \mathrm{Zn}_{0.7} \mathrm{Cu}_{0.3} \mathrm{O}$, (d) $\mathrm{Au} / \mathrm{Zn}_{0.5} \mathrm{Cu}_{0.5} \mathrm{O},(\mathrm{e}) \mathrm{Au} / \mathrm{Zn}_{0.3} \mathrm{Cu}{ }_{0.7} \mathrm{O}$, (f) $\mathrm{Au} / \mathrm{Zn}_{0.1} \mathrm{Cu} \mathrm{Cu}_{0.9} \mathrm{O}$, and (g) $\mathrm{Au} / \mathrm{CuO}$. 

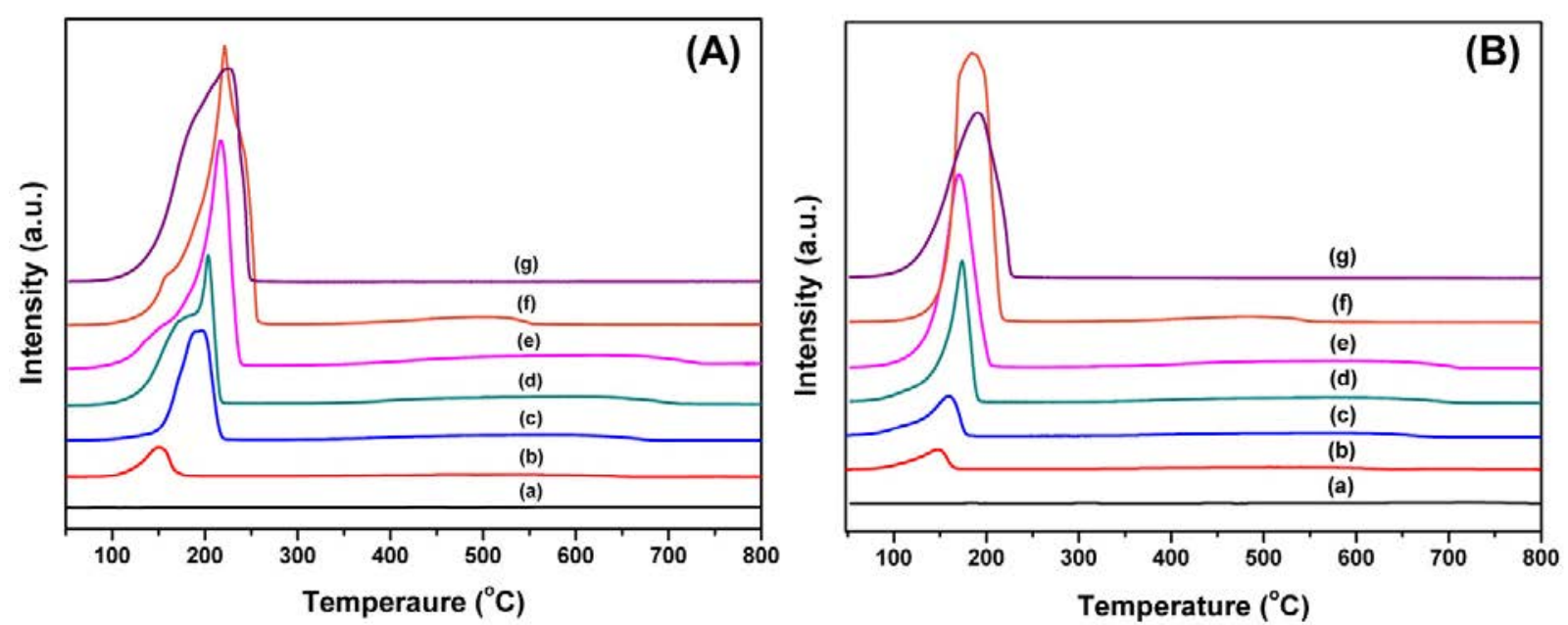

Fig. 2. (A) $\mathrm{H}_{2}$-TPR profiles of support materials: (a) $\mathrm{ZnO}$, (b) $\mathrm{Zn}_{0.9} \mathrm{Cu}_{0.1} \mathrm{O}$, (c) $\mathrm{Zn}_{0.7} \mathrm{Cu}_{0.3} \mathrm{O}$, (d) $\mathrm{Zn}_{0.5} \mathrm{Cu}_{0.5} \mathrm{O}$, (e) $\mathrm{Zn}_{0.3} \mathrm{Cu}_{0.7} \mathrm{O}$, (f) $\mathrm{Zn}_{0.1} \mathrm{Cu}_{0.9} \mathrm{O}$, and (g) $\mathrm{CuO}$; (B) $\mathrm{H}_{2}$-TPR profiles of supported gold catalysts: (a) $\mathrm{Au} / \mathrm{ZnO}$, (b) $\mathrm{Au} / \mathrm{Zn}_{0.9} \mathrm{Cu}_{0.1} \mathrm{O}$, (c) $\mathrm{Au} / \mathrm{Zn}_{0.7} \mathrm{Cu}_{0.3} \mathrm{O}$, (d) $\mathrm{Au} / \mathrm{Zn}_{0.5} \mathrm{Cu}_{0.5} \mathrm{O}$, (e) $\mathrm{Au} / \mathrm{Zn}_{0.3} \mathrm{Cu}_{0.7} \mathrm{O}$, (f) $\mathrm{Au} / \mathrm{Zn}_{0.1} \mathrm{Cu}_{0.9} \mathrm{O}$ and $(\mathrm{g}) \mathrm{Au} / \mathrm{CuO}$.

the reducibility of the copper species, probably owing to that $\mathrm{ZnO}$ promotes the dispersion of copper oxides [32]. It has been reported that the hydrogen reduction took place more easily on the surface copper oxide species than on the bulk $\mathrm{CuO}$ [33]. Therefore, the shoulder peak is attributed to the reduction of highly dispersed $\mathrm{CuO}$, while the major peak is owing to the reduction of bulk $\mathrm{CuO}$ [34]. As shown in Fig. 2(B), the reduction behavior of the supported gold catalysts is significantly different from that of corresponding supports. When gold was deposited on the surface of support materials, the shoulder reduction peaks of mixed oxides disappeared, and only one reduction peak could be observed. Compared to the corresponding supports, the reduction peaks of gold catalysts are shifted to lower temperatures, which are attributed to the strong interaction between $\mathrm{Au}$ NPs and supports. Such metal-support interaction will be conducive to achieving high catalytic activities in alcohol oxidation [35].

The textural properties of gold catalysts are listed in Table 1. It should be mentioned that the addition of $\mathrm{Cu}$ into $\mathrm{ZnO}$ influences the textural properties of the oxides. The surface area of the mixed oxides first increased with the addition of $\mathrm{Cu}$ and then decreased upon the further addition of $\mathrm{Cu}$. The gold catalysts with $\mathrm{Cu} / \mathrm{Zn}$ molar ratio in the range of $0-7 / 3$ possessed surface areas of 17.3-30.6 $\mathrm{m}^{2} / \mathrm{g}$, which are larger

Table 1

Textural properties and actual gold loading of the supported gold catalysts.

\begin{tabular}{|c|c|c|c|c|}
\hline Sample & $\begin{array}{c}\text { Surface area } \\
\left(\mathrm{m}^{2} / \mathrm{g}\right)\end{array}$ & $\begin{array}{l}\text { Pore volume } \\
\left(\mathrm{cm}^{3} / \mathrm{g}\right)\end{array}$ & $\begin{array}{l}\text { Average pore } \\
\text { diameter }(\mathrm{nm})\end{array}$ & $\begin{array}{c}\text { Au loading a } \\
(\mathrm{wt} \%)\end{array}$ \\
\hline $\mathrm{Au} / \mathrm{ZnO}$ & 18.99 & 0.09 & 19.63 & 2.01 \\
\hline $\mathrm{Au} / \mathrm{Zn}_{0.9} \mathrm{Cu}_{0.1} \mathrm{O}$ & 24.52 & 0.14 & 23.51 & 2.02 \\
\hline $\mathrm{Au} / \mathrm{Zn}_{0.7} \mathrm{Cu}_{0.3} \mathrm{O}$ & 23.35 & 0.12 & 20.91 & 2.12 \\
\hline $\mathrm{Au} / \mathrm{Zn}_{0.5} \mathrm{Cu}_{0.5} \mathrm{O}$ & 30.64 & 0.24 & 31.73 & 2.15 \\
\hline $\mathrm{Au} / \mathrm{Zn}_{0.3} \mathrm{Cu}_{0.7} \mathrm{O}$ & 17.34 & 0.10 & 24.04 & 2.36 \\
\hline $\mathrm{Au} / \mathrm{Zn}_{0.1} \mathrm{Cu}_{0.9} \mathrm{O}$ & 9.62 & 0.07 & 29.75 & 2.47 \\
\hline $\mathrm{Au} / \mathrm{CuO}$ & 5.82 & 0.02 & 10.53 & 2.56 \\
\hline
\end{tabular}

a Determined by ICP-OES technology. than that of $\mathrm{Au} / \mathrm{Zn}_{0.1} \mathrm{Cu}_{0.9} \mathrm{O}$ and $\mathrm{Au} / \mathrm{CuO}$. Larger surface area of the support was propitious to the deposition of smaller gold NPs and consequently improved the catalytic activity for alcohol oxidation [36]. The actual gold loadings were determined by ICP-OES measurement. As shown in Table 1, the real gold contents of the seven type catalysts $(2.01 \mathrm{wt} \%-2.56$ $w t \%)$ were less than the theoretical gold loading of $4 \mathrm{wt} \%$, indicating that there was a certain amount of gold loss during the process of deposition-precipitation.

Fig. 3 presents HAADF-STEM images of the gold catalysts. The Au particles were well dispersed on the supports of all catalysts, but homogeneous extent of them is a little different. The $\mathrm{Au}$ particles were less homogeneously dispersed on $\mathrm{Au} / \mathrm{Zn}_{0.1} \mathrm{Cu}_{0.9} \mathrm{O}$ and $\mathrm{Au} / \mathrm{CuO}$ than the counterparts, probably because of small surface areas of both samples. Fig. 3 also shows the size distribution of Au particles in gold catalysts. All the samples except $\mathrm{Au} / \mathrm{Zn}_{0.1} \mathrm{Cu}_{0.9} \mathrm{O}$ and $\mathrm{Au} / \mathrm{CuO}$ have narrow size distributions, with the mean sizes of $\mathrm{Au}$ particles in the range of $2.7-3.1 \mathrm{~nm}$. Among them, $\mathrm{Au} / \mathrm{Zn}_{0.7} \mathrm{Cu}_{0.3} \mathrm{O}$ possesses the smallest mean size of $\mathrm{Au}$ particles $(2.7 \mathrm{~nm})$ and the largest proportion $(18 \%)$ of gold clusters $(<2.0 \mathrm{~nm})$. In contrast, $\mathrm{Au} / \mathrm{Zn}_{0.1} \mathrm{Cu}_{0.9} \mathrm{O}$ and $\mathrm{Au} / \mathrm{CuO}$ have relatively wide size range of Au particles and comparatively large average size of 3.6 and 4.6 $\mathrm{nm}$ respectively, which may be due to the small surface areas of them. The $\mathrm{Au} / \mathrm{CuO}$ catalyst with the largest size of $\mathrm{Au}$ particles displayed the lowest benzyl alcohol conversion and very high benzaldehyde selectivity. Wang et al. [37] found that in the oxidation of benzyl alcohol, the conversion over Au/HT increased as the size of Au NPs decreased, while the selectivity to benzaldehyde was not related to the size of $\mathrm{Au}$ NPs. Therefore, the size of $\mathrm{Au}$ particles is a crucial factor affecting the catalytic activities of alcohol oxidation.

It has been reported that the acidic/basic properties of supports are important factors in influencing catalytic activities of gold catalysts for benzyl alcohol oxidation, and the supports with controllable acidic or basic properties are very necessary for gold catalysts to achieve both high catalytic activity and 

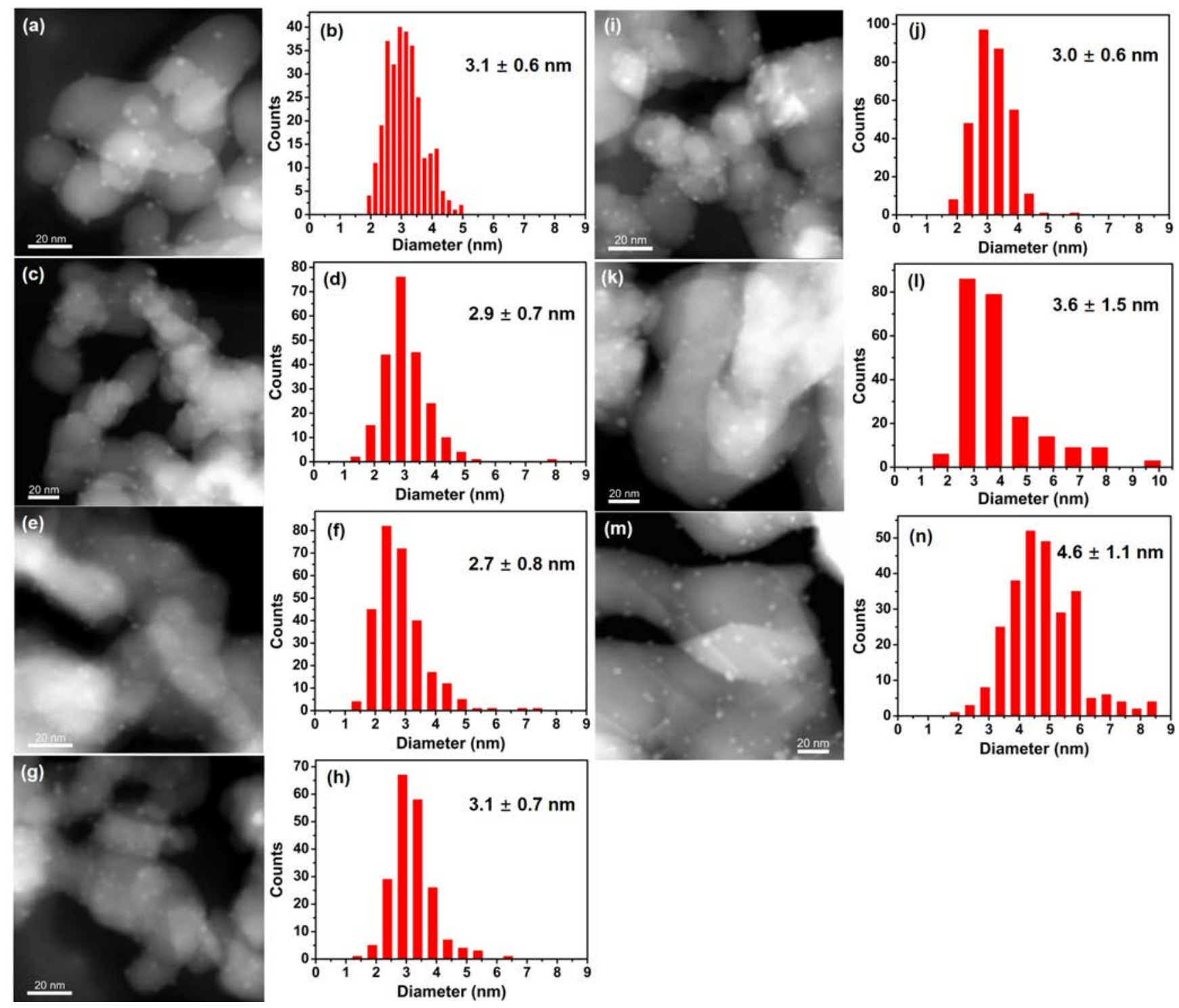

Fig. 3. HAADF-STEM images and the corresponding size distribution of Au particles of (a, b) $\mathrm{Au} / \mathrm{ZnO}$, (c, d) $\mathrm{Au} / \mathrm{Zn}_{0.9} \mathrm{Cu}_{0.1} \mathrm{O}$, (e, f) $\mathrm{Au} / \mathrm{Zn}_{0.7} \mathrm{Cu}_{0.3} \mathrm{O}$, (g, h) $\mathrm{Au} / \mathrm{Zn}_{0.5} \mathrm{Cu}_{0.5} \mathrm{O},(\mathrm{i}, \mathrm{j}) \mathrm{Au} / \mathrm{Zn}_{0.3} \mathrm{Cu}_{0.7} \mathrm{O},(\mathrm{k}, \mathrm{l}) \mathrm{Au} / \mathrm{Zn}_{0.1} \mathrm{Cu}_{0.9} \mathrm{O}$, and (m, n) Au/CuO.

excellent product selectivity [38,39]. Previous studies showed that $\mathrm{ZnO}$ was a material with only basic sites but no acidic sites, and the corresponding $\mathrm{Au} / \mathrm{ZnO}$ achieved high selectivity to benzaldehyde, but the conversion of benzyl alcohol was low $[40,41]$. In order to adjust the basic property of $\mathrm{ZnO}$ and introduce acidic sites, here we prepared a series of $\mathrm{CuO}$-modified $\mathrm{ZnO}$ supports. We evaluated the basic properties of $\mathrm{ZnO}-\mathrm{CuO}$ mixed oxide by $\mathrm{CO}_{2}$-TPD (Fig. 4). Three main $\mathrm{CO}_{2}$ desorption peaks can be observed at about 80,380 , and $570{ }^{\circ} \mathrm{C}$, which is due to the desorption of $\mathrm{CO}_{2}$ from weak, moderate, and strong basic sites, respectively [42]. Both weak and moderate basic sites are observed over $\mathrm{ZnO}$, and only weak basic sites are present over $\mathrm{CuO}$. Interestingly, the introduction of $\mathrm{CuO}$ to $\mathrm{ZnO}$ creates strong basic sites over the $\mathrm{ZnO}-\mathrm{CuO}$ mixed oxides. With the increase of $\mathrm{CuO}$ content, the number of basic sites of ZnO-CuO mixed oxides gradually decreased, especially for moderate and strong basic sites. Orel et al. [43] reported that $\mathrm{ZnO}-\mathrm{CuO}$ mixed oxides were acidic supports determined by
$\mathrm{NH}_{3}$-TPD characterization, and the amount of acidic sites increased with $\mathrm{Cu}$ content. Hutchings et al. [41] reported that the gold catalysts with both acidity and basicity displayed both high catalytic activity and excellent selectivity for benzyl alcohol oxidation. In this work, a series of $\mathrm{ZnO}-\mathrm{CuO}$ mixed oxides with both acidity and basicity were prepared by a co-precipitation method, which may be the suitable supports for gold catalysts for base-free aerobic oxidation of benzyl alcohol.

We further utilized $\mathrm{O}_{2}$-TPD to study the adsorption and activation of oxygen on the gold catalysts (Fig. 5). There are four oxygen desorption peaks in the $\mathrm{O}_{2}$-TPD profiles of gold catalysts except $\mathrm{Au} / \mathrm{ZnO}$. The peak at $94{ }^{\circ} \mathrm{C}$ is due to the desorption of physically adsorbed oxygen species. The two peaks at 270 and $380{ }^{\circ} \mathrm{C}$ are assigned to the desorption of chemisorbed surface oxygen species, while the peak at high temperature above $700{ }^{\circ} \mathrm{C}$ is attributed to the desorption of lattice oxygen species [44]. It is apparent that the introduction of $\mathrm{CuO}$ component to 


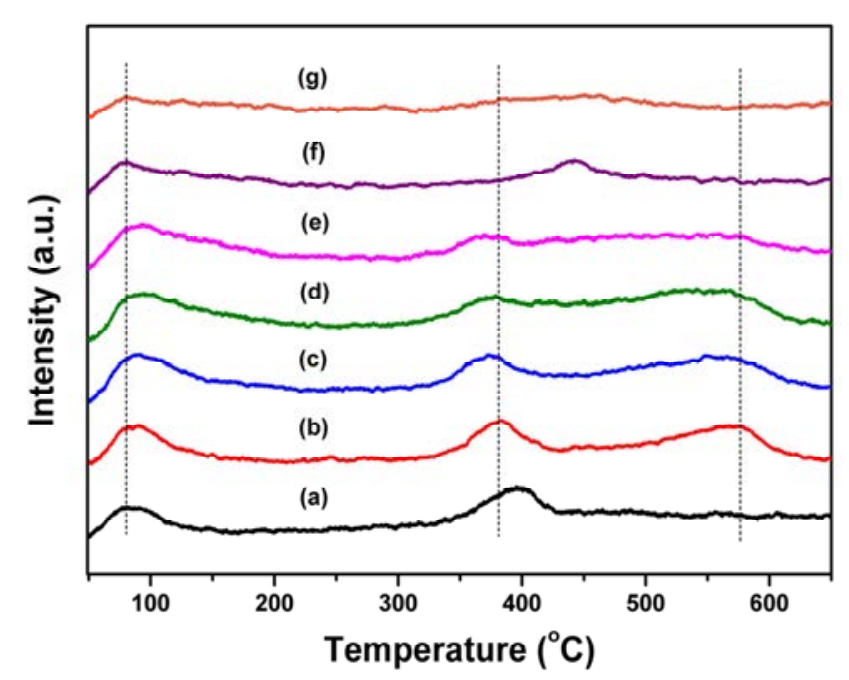

Fig. 4. $\mathrm{CO}_{2}$-TPD profiles of (a) $\mathrm{ZnO}$, (b) $\mathrm{Zn}_{0.9} \mathrm{Cu}_{0.1} \mathrm{O}$, (c) $\mathrm{Zn}_{0.7} \mathrm{Cu}_{0.3} \mathrm{O}$, (d) $\mathrm{Zn}_{0.5} \mathrm{Cu}_{0.5} \mathrm{O}$, (e) $\mathrm{Zn}_{0.3} \mathrm{Cu}_{0.7} \mathrm{O}$, (f) $\mathrm{Zn}_{0.1} \mathrm{Cu}_{0.9} \mathrm{O}$, and (g) $\mathrm{CuO}$.

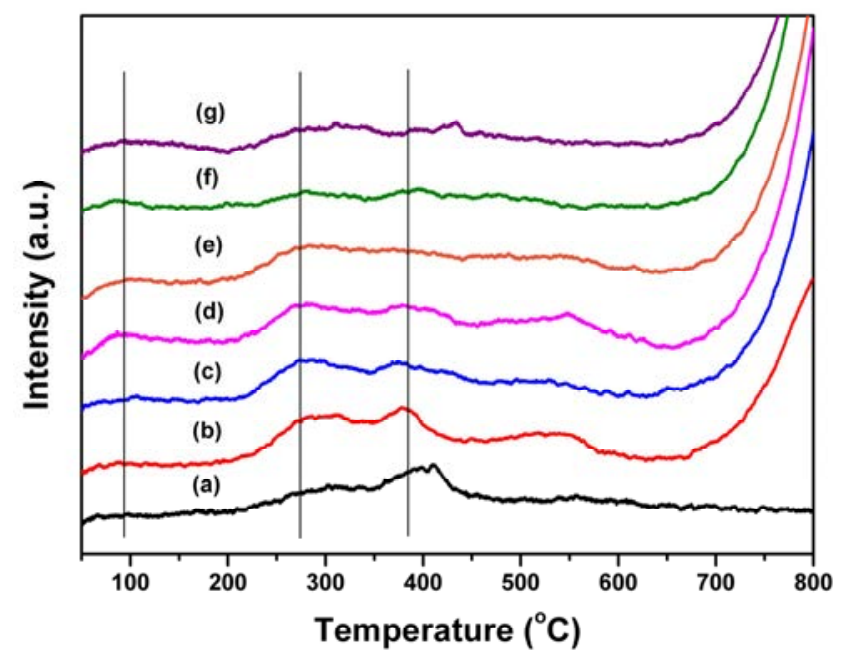

Fig. 5. $\mathrm{O}_{2}$-TPD profiles of (a) $\mathrm{Au} / \mathrm{ZnO}$, (b) $\mathrm{Au} / \mathrm{Zn}_{0.9} \mathrm{Cu}_{0.1} \mathrm{O}$, (c) $\mathrm{Au} / \mathrm{Zn}_{0.7} \mathrm{Cu}_{0.3} \mathrm{O}$, (d) $\mathrm{Au} / \mathrm{Zn}_{0.5} \mathrm{Cu}_{0.5} \mathrm{O}$, (e) $\mathrm{Au} / \mathrm{Zn}_{0.3} \mathrm{Cu}_{0.7} \mathrm{O}$, (f) $\mathrm{Au} / \mathrm{Zn}_{0.1} \mathrm{Cu}_{0.9} \mathrm{O}$, and $(\mathrm{g}) \mathrm{Au} / \mathrm{CuO}$.

$\mathrm{ZnO}$ substantially raises the amount of surface active oxygen species of $\mathrm{Au} / \mathrm{ZnO}-\mathrm{CuO}$ catalysts. The more surface active oxygen species of $\mathrm{Au} / \mathrm{ZnO}-\mathrm{CuO}$ catalysts are beneficial for promoting the catalytic oxidation of benzyl alcohol. The amount of surface active oxygen species of $\mathrm{Au} / \mathrm{ZnO}-\mathrm{CuO}$ catalysts decreases gradually with the increase of $\mathrm{Cu} / \mathrm{Zn}$ molar ratio.

\subsection{Catalytic activity}

The catalytic performance of gold catalysts for aerobic oxidation of benzyl alcohol was investigated at $120^{\circ} \mathrm{C}$ under 0.5 $\mathrm{MPa}$ of $\mathrm{O}_{2}$, and the results are presented in Table 2. The $\mathrm{Au} / \mathrm{ZnO}$ and $\mathrm{Au} / \mathrm{CuO}$ catalysts showed low conversion and very high selectivity to benzaldehyde. The $\mathrm{Au} /$ mixed oxide catalysts showed much better catalytic performance than $\mathrm{Au} / \mathrm{ZnO}$ and $\mathrm{Au} / \mathrm{CuO}$ catalysts. The $\mathrm{Au} / \mathrm{ZnO}-\mathrm{CuO}$ catalysts displayed very high conversion of benzyl alcohol as well as high selectivity to benzaldehyde. The results imply that $\mathrm{ZnO}-\mathrm{CuO}$ mixed oxides
Table 2

The aerobic oxidation of benzyl alcohol over the gold catalysts.

\begin{tabular}{|c|c|c|c|c|c|c|c|}
\hline \multirow{2}{*}{ Catalyst } & \multirow{2}{*}{$\begin{array}{c}\text { Conversion } \\
\text { (\%) }\end{array}$} & \multicolumn{3}{|c|}{ Selectivity (\%) } & \multirow{2}{*}{$\begin{array}{c}\text { Yield } \\
\text { of a } \\
(\%)\end{array}$} & \multirow{2}{*}{$\begin{array}{c}\mathrm{Au} \\
\text { dispersion } \\
(\%)\end{array}$} & \multirow{2}{*}{$\begin{array}{l}\text { TOF } \\
\left(\mathrm{h}^{-1}\right)\end{array}$} \\
\hline & & $\mathrm{a}$ & $\mathrm{b}$ & c & & & \\
\hline$\overline{\mathrm{Au} / \mathrm{ZnO}}$ & 49 & 98 & 0 & 2 & 48 & 38 & 935 \\
\hline $\mathrm{Au} / \mathrm{Zn}_{0.9} \mathrm{Cu}_{0.1} \mathrm{O}$ & 88 & 99 & 0 & 1 & 87 & 40 & 1547 \\
\hline $\mathrm{Au} / \mathrm{Zn}_{0.7} \mathrm{Cu}_{0.3} \mathrm{O}$ & 93 & 99 & 0 & 1 & 92 & 43 & 1973 \\
\hline $\mathrm{Au} / \mathrm{Zn}_{0.5} \mathrm{Cu}_{0.5} \mathrm{O}$ & 90 & 99 & 0 & 1 & 89 & 38 & 1748 \\
\hline $\mathrm{Au} / \mathrm{Zn}_{0.3} \mathrm{Cu}_{0.7} \mathrm{O}$ & 94 & 97 & 2 & 1 & 91 & 39 & 1626 \\
\hline $\mathrm{Au} / \mathrm{Zn}_{0.1} \mathrm{Cu}_{0.9} \mathrm{O}$ & 85 & 99 & 0 & 1 & 84 & 33 & 1226 \\
\hline $\mathrm{Au} / \mathrm{CuO}$ & 46 & 99 & 0 & 1 & 46 & 25 & 968 \\
\hline
\end{tabular}

Reaction condition: catalyst (Au: $0.16 \mathrm{~mol} \%$ ), $2 \mathrm{mmol}$ benzyl alcohol, 1 mmol nonane, $8 \mathrm{~mL}$ toluene, $0.5 \mathrm{MPa} \mathrm{O}_{2}, 120^{\circ} \mathrm{C}, 5 \mathrm{~h}$.

are the promising support candidates of gold catalysts for attaining the high catalytic performance for benzyl alcohol oxidation. The difference between catalytic activities of mixed oxide-supported gold catalysts is relatively small. Among all the mixed oxide-supported catalysts, $\mathrm{Au} / \mathrm{Zn}_{0.7} \mathrm{Cu}_{0.3} \mathrm{O}$ exhibits the highest benzaldehyde yield. Although $\mathrm{Au} / \mathrm{Zn}_{0.3} \mathrm{Cu}_{0.7} \mathrm{O}$ displayed the highest benzyl alcohol conversion, its benzaldehyde selectivity is lower than that of the other mixed oxide-supported gold catalysts and a small amount of benzoic acid is also produced. For all the catalysts except for $\mathrm{Au} / \mathrm{Zn}_{0.3} \mathrm{Cu}_{0.7} \mathrm{O}$, the selectivity to benzaldehyde was almost $99 \%$, and only a little benzyl benzoate $(1 \%)$ was detected.

Because the reaction took place on the catalyst surface, we calculated the $\mathrm{Au}$ dispersion $(D)$ to estimate the number of surface gold atoms in the catalyst. By assuming the spherical model of Au NPs, the Au dispersion was roughly estimated by the following relationship, $D=1.17 / d_{\mathrm{Au}} \times 100 \%$, where $d_{\mathrm{Au}}$ means the average diameter of Au NPs [39]. The calculated gold dispersion is listed in Table 2. In order to evaluate the intrinsic activities of these gold catalysts, we calculated turnover frequency (TOF) at initial reaction stage based on surface gold atoms (Table 2). The TOF values of these gold catalysts first increased and then decreased with the rise of $\mathrm{Cu} / \mathrm{Zn}$ molar ratio. The highest TOF value $\left(1973 \mathrm{~h}^{-1}\right)$ was achieved over $\mathrm{Au} / \mathrm{Zn} 0.7 \mathrm{Cu}_{0.3} \mathrm{O}$.

The influence of reaction temperature on the catalytic activities for aerobic oxidation of benzyl alcohol over $\mathrm{Au} / \mathrm{Zn}_{0.7} \mathrm{Cu}_{0.3} \mathrm{O}$ was investigated (Table 3). With the rise of the reaction temperature from 100 to $120{ }^{\circ} \mathrm{C}$, the conversion of benzyl alcohol increased significantly from $63 \%$ to $93 \%$, while the high selectivity to benzaldehyde (99\%) was unchanged. Both excellent conversion and selectivity were achieved when the reaction was carried out at $120^{\circ} \mathrm{C}$. Upon further increasing reaction temperature to $140{ }^{\circ} \mathrm{C}$, the conversion of benzyl alcohol slightly increased to $95 \%$, while the selectivity toward benzaldehyde decreased to $97 \%$. A small amount of benzoic acid was obtained due to subsequent oxidation of benzaldehyde at higher reaction temperature. Therefore, the 
Table 3

Effect of reaction temperature and oxygen pressure on catalytic performance of $\mathrm{Au} / \mathrm{Zn}_{0.7} \mathrm{Cu}_{0.3} \mathrm{O}$ in the aerobic oxidation of benzyl alcohol.

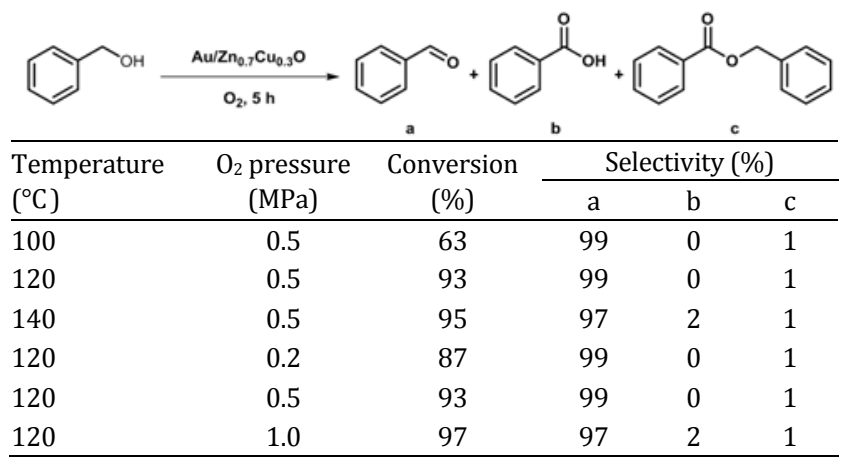

Reaction conditions: catalyst (Au: $0.16 \mathrm{~mol} \%), 2 \mathrm{mmol}$ benzyl alcohol, 1 mmol nonane, $8 \mathrm{~mL}$ toluene, $5 \mathrm{~h}$.

above results imply that the best reaction temperature for aerobic oxidation of benzyl alcohol is about $120^{\circ} \mathrm{C}$. The effect of oxygen pressure on the catalytic performance of was also investigated, and the results are depicted in Table 3. The oxygen pressure was found to have moderate effect on the catalytic performance of the catalyst. When the oxygen pressure was raised from 0.2 to $0.5 \mathrm{MPa}$, the conversion of benzyl alcohol increased from $87 \%$ to $93 \%$, and the selectivity to benzaldehyde was retained. Upon further increasing the oxygen pressure to $1.0 \mathrm{MPa}$, nearly full conversion of benzyl alcohol was achieved, while the selectivity toward benzaldehyde tended to decrease with a small amount of benzoic acid formed. This manifests that increasing the oxygen pressure will lead to more oxygen dissolved in the solution, thereby improving the conversion of benzyl alcohol, but simultaneously causing over oxidation of benzyl alcohol to form benzoic acid.

To further explore the substrate applicability of $\mathrm{Au} / \mathrm{Zn}_{0.7} \mathrm{Cu}_{0.3} \mathrm{O}$, the catalytic performance for oxidation of various alcohols was studied using $\mathrm{O}_{2}$ without base. As summarized in Table 4, the $\mathrm{Au} / \mathrm{Zn}_{0.7} \mathrm{Cu}_{0.3} \mathrm{O}$ catalyst showed high catalytic activities for aerobic oxidation of a wide variety of benzylic alcohols, producing the corresponding carbonyl compounds with yields of $99 \%$ at $120{ }^{\circ} \mathrm{C}$ under $0.5 \mathrm{MPa}$ of $\mathrm{O}_{2}$ pressure. It is worth mentioning that $\alpha$-cyclopropybenzyl alcohol was exclusively oxidized to cyclopropyl phenyl ketone over $\mathrm{Au} / \mathrm{Zn}_{0.7} \mathrm{Cu}_{0.3} \mathrm{O}$ without affecting the unstable cyclopropyl ring (entry 10). In the aerobic oxidation of cinnamyl alcohol, a typical allylic alcohol, only cinnamaldehyde was obtained without observing other side products when the reactions were conducted at 120 or $130^{\circ} \mathrm{C}$ under $0.5 \mathrm{MPa}$ of $\mathrm{O}_{2}$ pressure. It is well known that reaction condition has a great influence on the selectivity of cinnamyl alcohol oxidation, because the reaction network is complicated [45]. The conversion of cinnamyl alcohol increased from $67 \%$ to $85 \%$ with the rise in reaction temperature from 120 to $130{ }^{\circ} \mathrm{C}$. When the reaction was conducted at $140{ }^{\circ} \mathrm{C}$ under $1.0 \mathrm{MPa}$ of $\mathrm{O}_{2}$ pressure, nearly completely conversion (99\%) of cinnamyl alcohol was achieved, while the cinnamaldehyde selectivity decreased to $75 \%$ with benzaldehyde as the main side product. We also
Table 4

The aerobic oxidation of various alcohols catalyzed by $\mathrm{Au} / \mathrm{Zn}_{0.7} \mathrm{Cu}_{0.3} \mathrm{O}$ a

\begin{tabular}{|c|c|c|c|c|c|}
\hline Entry & Substrate & Product & Conv. (\%) & Sel. (\%) & Yield (\%) \\
\hline 1 & & & 93 & 99 & 92 \\
\hline 2 & reuse 1 & & 72 & 99 & 71 \\
\hline 3 & & & 99 & 100 & 99 \\
\hline 4 & reuse 1 & & 96 & 100 & 96 \\
\hline 5 & reuse 2 & & 95 & 100 & 95 \\
\hline 6 & reuse 3 & & 92 & 100 & 92 \\
\hline 7 & & & 99 & 100 & 99 \\
\hline 8 & & & 99 & 100 & 99 \\
\hline 9 & & & 99 & 100 & 99 \\
\hline 10 & & & 99 & 100 & 99 \\
\hline 11 & & & 67 & 100 & 67 \\
\hline $12^{[\mathrm{b}]}$ & & & 85 & 100 & 85 \\
\hline $13^{[c]}$ & & & 99 & 75 & 74 \\
\hline $14^{[\mathrm{d}]}$ & & & 23 & 92 & 21 \\
\hline
\end{tabular}

a Reaction conditions: catalyst (Au: $0.16 \mathrm{~mol} \%), 2 \mathrm{mmol}$ substrate, 1 mmol nonane, $8 \mathrm{~mL}$ toluene, $0.5 \mathrm{MPa} \mathrm{O}_{2}, 120^{\circ} \mathrm{C}, 5$ h. b $0.5 \mathrm{MPa} \mathrm{O}_{2}, 130$ ${ }^{\circ} \mathrm{C}$. ${ }^{1.0} \mathrm{MPa} \mathrm{O}_{2}, 140{ }^{\circ} \mathrm{C}$. d $10 \mathrm{~h}$.

studied the catalytic performance of $\mathrm{Au} / \mathrm{Zn}_{0.7} \mathrm{Cu}_{0.3} \mathrm{O}$ for aerobic oxidation of aliphatic alcohol (1-octanol) with long alkyl chain. Although high selectivity to octanal of $92 \%$ was achieved, the conversion of 1-octanol was relatively low (only 23\%) even after reaction for $10 \mathrm{~h}$.

As the catalyst recyclability is a very important issue in heterogeneous catalysis, we further carried out experiments to study the recyclability of $\mathrm{Au} / \mathrm{Zn}_{0.7} \mathrm{Cu}_{0.3} \mathrm{O}$ for alcohol oxidation. As presented in Table 4, the conversion of benzyl alcohol over $\mathrm{Au} / \mathrm{Zn}_{0.7} \mathrm{Cu}_{0.3} \mathrm{O}$ decreased from $93 \%$ to $72 \%$ after the fresh catalyst being first reused for benzyl alcohol oxidation, but the high selectivity toward benzaldehyde was kept. However, the recyclability of $\mathrm{Au} / \mathrm{Zn}_{0.7} \mathrm{Cu}_{0.3} \mathrm{O}$ for the aerobic oxidation of 1-phenylethanol was significantly different. The $\mathrm{Au} / \mathrm{Zn}_{0.7} \mathrm{Cu}_{0.3} \mathrm{O}$ catalyst could enable the reaction cycle for selective oxidation of 1-phenylethanol to proceed smoothly. After the third reuse, only a slight decrease of conversion was observed and the high selectivity to acetophenone was retained. The previous studies showed that the gold catalyst is easily deactivated when reused for aerobic oxidation of benzyl alcohol $[46,47]$, but is more stable for recycling reaction of aerobic oxidation of 1-phenylethanol [22]. In order to explain the different behavior of $\mathrm{Au} / \mathrm{Zn}_{0.7} \mathrm{Cu}_{0.3} \mathrm{O}$ in the recycle tests of aerobic oxidation of benzyl alcohol and 1-pheylethanol, HR-TEM was used to characterize the re-used $\mathrm{Au} / \mathrm{Zn}_{0.7} \mathrm{Cu}_{0.3} \mathrm{O}$. The results showed that after reuse of $\mathrm{Au} / \mathrm{Zn}_{0.7} \mathrm{Cu}_{0.3} \mathrm{O}$ only one time in benzyl 
alcohol oxidation, the mean size of Au NPs increased obviously from 2.7 to $5.6 \mathrm{~nm}$, and the coagulation of Au NPs during the reaction was serious. However, even after reuse of $\mathrm{Au} / \mathrm{Zn}_{0.7} \mathrm{Cu}_{0.3} \mathrm{O}$ three times in 1-phenylthanol oxidation, the mean size of Au NPs increased only slightly from 2.7 to $3.5 \mathrm{~nm}$. Therefore, the size growth of Au NPs is a main reason for the deactivation of $\mathrm{Au} / \mathrm{Zn}_{0.7} \mathrm{Cu}_{0.3} \mathrm{O}$ in the recycling reaction of benzyl alcohol oxidation.

\subsection{Discussion}

It is widely accepted that the aerobic oxidation of alcohol over gold catalysts involves a process of three main steps $[41,47,48]$. Based on the previous reaction mechanism studies and our experimental results, a possible reaction pathway of the benzyl alcohol oxidation is proposed (Scheme 1). In the first step, the proton of benzyl alcohol is abstracted by the basic hydroxyl groups on the support to form an alkoxide intermediate. In the second step, the alkoxide intermediate would proceed $\beta-\mathrm{H}$ elimination to give the corresponding carbonyl compound and gold-hydride intermediate. The cleavage of $\mathrm{C}-\mathrm{H}$ bond is widely recognized as the rate-determining step in the entire catalytic cycle [47]. In the third step, the gold-hydride species is rapidly oxidized by oxygen to produce water, probably proceeding through hydrogen peroxide formation. It is well known that the coordinatively unsaturated metal atoms facilitate the cleavage of the $\mathrm{C}-\mathrm{H}$ bond [41]. Small gold particles have a larger proportion of coordinatively unsaturated sites, providing more active sites for cleavage of the $\mathrm{C}-\mathrm{H}$ bond of alcohol. Hence, the catalyst with smaller gold particles exhibited higher catalytic activity for alcohol oxidation. The mixed oxides-supported gold catalysts except $\mathrm{Au} / \mathrm{Zn}_{0.1} \mathrm{Cu} 0.9 \mathrm{O}$ have almost similar mean diameter of gold particles $(2.7-3.1 \mathrm{~nm})$ and give similarly high benzyl alcohol conversions (88\%-94\%) after $5 \mathrm{~h}$ of reaction. The $\mathrm{Au} / \mathrm{Zn}_{0.1} \mathrm{Cu}_{0.9} \mathrm{O}$ and $\mathrm{Au} / \mathrm{CuO}$ catalysts have larger size of

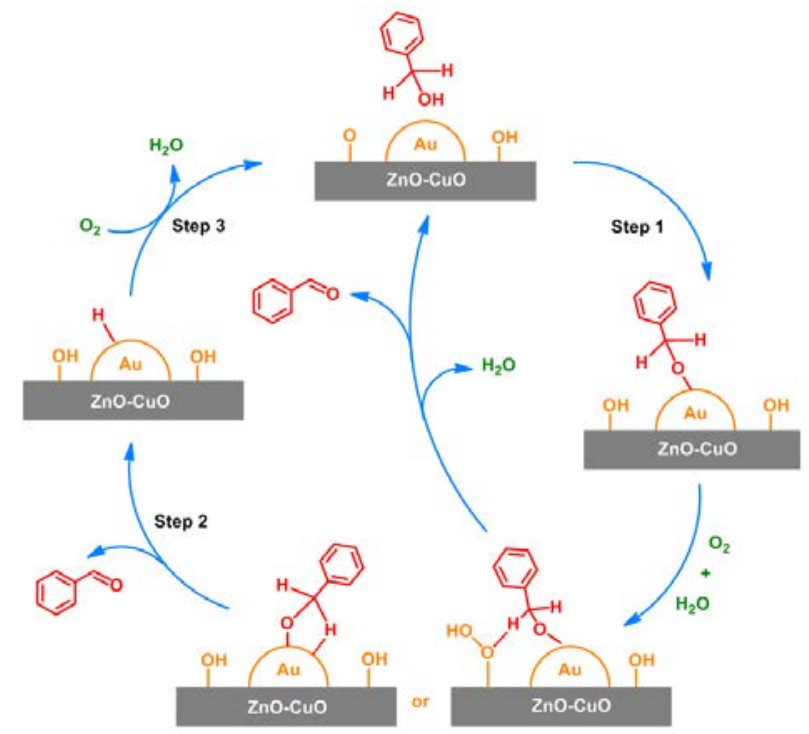

Scheme 1. The possible reaction pathway of the aerobic oxidation of benzyl alcohol over gold catalyst. gold particles than other catalysts and consequently gave the lower benzyl alcohol conversion. Among all the mixed oxides-supported gold catalysts, the $\mathrm{Au} / \mathrm{Zn}_{0.7} \mathrm{Cu}_{0.3} \mathrm{O}$ catalyst was considered to be the most active for cleavage of $\mathrm{C}-\mathrm{H}$ bond of alcohol, due to the smallest size of gold and the largest proportion of gold clusters in the catalyst, exhibiting the highest benzaldehyde yield.

On the other hand, the catalytic activity for oxidation reaction is usually related to the ability to activate oxygen [49]. Tsukuda et al. [50,51] put forward that during the oxidation of alcohol catalyzed by gold clusters, the superoxo-like species formed on the surface is important for eliminating the $\beta$-hydride of the alcohol. Davis et al. [52] studied the mechanism of alcohol oxidation over gold catalysts and proposed that molecular oxygen takes part in the reaction by forming hydroxide ions instead of directly dissociating to oxygen atoms. A small amount of water could be produced during the first step $[37,41,53]$. It has been reported that water can promote oxygen activation over gold catalyst to form hydroperoxo species [54-56]. The hydroperoxo species might take part in abstracting the $\beta$-hydride of the alcohol. In addition, the oxygen activation capability of a catalyst is often correlated with its redox properties [57]. The poor redox properties of $\mathrm{Au} / \mathrm{ZnO}$ might be the reason why the catalyst with small gold particle size showed low conversion of benzyl alcohol. The good low-temperature reducibility of $\mathrm{Au} / \mathrm{ZnO}-\mathrm{CuO}$ catalysts is conducive to achieving the high catalytic activity in benzyl alcohol oxidation.

\section{Conclusions}

A series of $\mathrm{ZnO}-\mathrm{CuO}$ mixed oxides-supported $\mathrm{Au}$ NPs were synthesized and the Au NPs were uniformly dispersed with the mean diameter in the range of 2.7-4.6 $\mathrm{nm}$. In the base-free aerobic oxidation of benzyl alcohol, the mixed oxide-supported gold catalysts showed much better catalytic activity than the $\mathrm{Au} / \mathrm{ZnO}$ and $\mathrm{Au} / \mathrm{CuO}$ catalysts. Among them, $\mathrm{Au} / \mathrm{Zn}_{0.7} \mathrm{Cu}_{0.3} \mathrm{O}$ displayed the best catalytic performance. Such excellent catalytic performance of $\mathrm{Au} / \mathrm{Zn}_{0.7} \mathrm{Cu}_{0.3} \mathrm{O}$ might be correlated with the small size of Au NPs, good low-temperature reducibility, high concentration of surface oxygen species, and collaborative interaction between $\mathrm{Au}$ NPs and mixed oxides. More importantly, the $\mathrm{Au} / \mathrm{Zn}_{0.7} \mathrm{Cu}_{0.3} \mathrm{O}$ catalyst also exhibited excellent performance for the aerobic oxidation of a wide range of alcohols under mild conditions without base. It is demonstrated that the $\mathrm{ZnO}-\mathrm{CuO}$ mixed oxides are promising materials as supports for the fabrication of highly active gold catalysts for aerobic oxidation of alcohols under mild conditions.

\section{References}

[1] M. Liu, G. Fan, J. Yu, L. Yang, F. Li, Dalton Trans., 2018, 47, 5226-5235.

[2] K. Mori, T. Hara, T. Mizugaki, K. Ebitani, K. Kaneda, J. Am. Chem. Soc., 2004, 126, 10657-10666.

[3] Y. Hao, S. Wang, Q. Sun, L. Shi, A. Lu, Chin. J. Catal., 2015, 36, 612-619. 


\section{Graphical Abstract}

Chin. J. Catal., 2019, 40: 1924-1933 doi: S1872-2067(19)63429-7

Highly efficient base-free aerobic oxidation of alcohols over gold nanoparticles supported on $\mathrm{ZnO}-\mathrm{CuO}$ mixed oxides

Wei Wang, Yan Xie*, Shaohua Zhang, Xing Liu, Liyun Zhang, Bingsen Zhang, Masatake Haruta, Jiahui Huang *

Dalian Institute of Chemical Physics, Chinese Academy of Sciences, China; University of Chinese Academy of Sciences, China; Institute of Metal Research, Chinese Academy of Sciences, China; Tokyo Metropolitan University, Japan

The $\mathrm{Au} / \mathrm{Zn}_{0.7} \mathrm{Cu}_{0.3} \mathrm{O}$ catalyst showed excellent catalytic performance for aerobic oxidation of a wide range of alcohols, affording the corresponding carbonyl compounds with high yields under mild conditions without base.

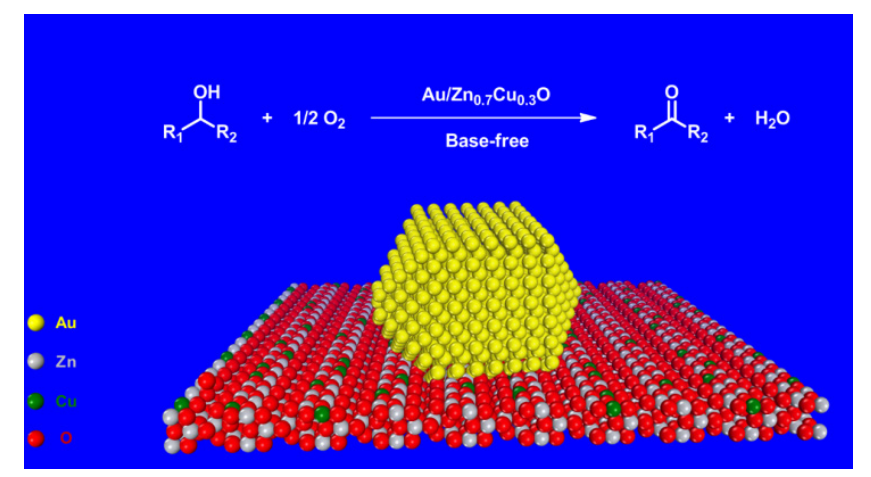

mun., 2011, 47, 11540-11542.

[25] J. Albadi, A. Alihoseinzadeh, A. Razeghi, Catal. Commun., 2014, 49, $1-5$.

[26] Z. Wu, J. Deng, Y. Liu, S. Xie, Y. Jiang, X. Zhao, J. Yang, H. Arandiyan, G. Guo, H. Dai, J. Catal., 2015, 332, 13-24.

[27] H. Yang, F. Chang, L. S. Roselin, J. Mol. Catal. A, 2007, 276, 184-190.

[28] Y. Liu, H. Dai, J. Deng, X. Li, Y. Wang, H. Arandiyan, S. Xie, H. Yang, G. Guo, J. Catal., 2013, 305, 146-153.

[29] J. Xiao, D. Mao, X. Guo, J. Yu, Appl. Surf. Sci, 2015, 338, 146-153.

[30] I. Melián-Cabrera, M. L. Granados, J. L. G. Fierro, J. Catal., 2002, 210, 273-284.

[31] T. Shishido, M. Yamamoto, D. Li, Y. Tian, H. Morioka, M. Honda, T. Sano, K. Takehira, Appl. Catal. A, 2006, 303, 62-71.

[32] X. Guo, D. Mao, G. Lu, S. Wang, G. Wu, J. Catal, 2010, 271, 178-185.

[33] G. Fierro, M. Lo Jacono, M. Inversi, P. Porta, F. Cioci, R. Lavecchia, Appl. Catal. A, 1996, 137, 327-348.

[34] M. Răciulete, G. Layrac, D. Tichit, I. C. Marcu, Appl. Catal. A, 2014, 477, 195-204.

[35] Y. Wei, J. Liu, Z. Zhao, A. Duan, G. Jiang, J. Catal., 2012, 287, 13-29.

[36] T. Takei, J. Suenaga, T. Ishida, M. Haruta, Top. Catal., 2015, 58, 295-301.

[37] J. Chen, W. Fang, Q. Zhang, W. Ding, Y. Wang, Chem. Asian J., 2014, 9, 2187-2196.

[38] A. Villa, C. E. Chan-Thaw, G. M. Veith, K. L. More, D. Ferri, L. Prati, ChemCatChem, 2011, 3, 1612-1618.

[39] W. Fang, J. Chen, Q. Zhang, W. Deng, Y. Wang, Chem. Eur. J., 2011, $17,1247-1256$.

[40] M. Sankar, E. Nowicka, R. Tiruvalam, Q. He, S. H. Taylor, C. J. Kiely, D. Bethell, D. W. Knight, G. J. Hutchings, Chem. Eur. J., 2011, 17, 6524-6532.

[41] J. Feng, C. Ma, P. J. Miedziak, J. K. Edwards, G. L. Brett, D. Li, Y. Du, D. J. Morgan, G. J. Hutchings, Dalton Trans., 2013, 42, 14498-14508.

[42] Z. Shi, Q. Tan, D. Wu, Appl. Catal. A, 2019, 581, 58-66.

[43] Š. Hajduk, V. Dasireddy, B. Likozar, G. Dražić, Z. C. Orel, Appl. Catal. $B$, 2017, 211, 57-67.

[44] Y. Wei, J. Liu, Z. Zhao, A. Duan, G. Jiang, C. Xu, J. Gao, H. He, X. Wang, Energy Environ. Sci., 2011, 4, 2959-2970.

[45] E. Rucinska, P. J. Miedziak, S. Pattisson, G. L. Brett, S. Iqbal, D. J. Morgan, M. Sankar, G. J. Hutchings, Catal. Sci. Technol., 2018, 8, 2987-2997. 
[46] P. J. Miedziak, Z. Tang, T. E. Davies, D. I. Enache, J. K. Bartley, A. F. Carley, A. A. Herzing, C. J. Kiely, S. H. Taylor, G. J. Hutchings, J. Mater. Chem., 2009, 19, 8619-8627.

[47] A. Abad, A. Corma, H. García, Chem. Eur. J., 2008, 14, 212-222.

[48] M. Conte, H. Miyamura, S. Kobayashi, V. Chechik, J. Am. Chem. Soc., 2009, 131, 7189-7196.

[49] Y. Wei, J. Liu, Z. Zhao, Y. Chen, C. Xu, A. Duan, G. Jiang, H. He, Angew. Chem. Int. Ed., 2011, 50, 2326-2329.

[50] H. Tsunoyama, N. Ichikuni, H. Sakurai, T. Tsukuda, J. Am. Chem. Soc., 2009, 131, 7086-7093.

[51] H. Tsunoyama, H. Sakurai, Y. Negishi, T. Tsukuda, J. Am. Chem. Soc., 2005, 127, 9374-9375.
[52] B. N. Zope, D. D. Hibbitts, M. Neurock, R. J. Davis, Science, 2010, 330, 74-78.

[53] K. Shimizu, K. Sugino, K. Sawabe, A. Satsuma, Chem. Eur. J., 2009, 15, 2341-2351.

[54] M. Daté, M. Okumura, S. Tsubota, M. Haruta, Angew. Chem. Int. Ed., 2004, 43, 2129-2132.

[55] J. Huang, T. Akita, J. Faye, T. Fujitani, T. Takei, M. Haruta, Angew. Chem. Int. Ed., 2009, 48, 7862-7866.

[56] J. Saavedra, H. A. Doan, C. J. Pursell, L. C. Grabow, B. D. Chandler, Science, 2014, 345, 1599-1602.

[57] Z. Yan, Z. Xu, L. Yue, L. Shi, L. Huang, Chin. J. Catal., 2018, 39, 1919-1928.

\title{
锌铜复合氧化物负载的金纳米粒子在无碱条件下催化多种醇高效选择性氧化
}

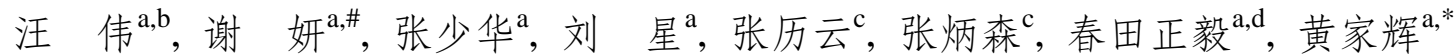 \\ ${ }^{a}$ 中国科学院大连化学物理研究所, 催化基础国家重点实验室, 金催化研究中心, 辽宁大连116023, 中国

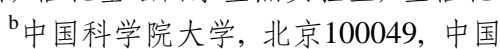 \\ c中国科学院金属研究所, 沈阳材料科学国家研究中心, 辽宁沈阳110016, 中国 \\ d首都大学东京, 大学院都市环境科学研究科, 金化学研究中心, 八王子市, 东京192-0397, 日本
}

摘要: 醇选择性氧化为醛和酮是化学工业上的重要反应. 醛和酮是广泛应用于合成医药、农药和香料等精细化学品的重要 化学中间体. 过去常用化学计量的氧化剂来实现醇的选择性氧化, 但会带来严重的环境污染. 目前, 很多研究工作致力于 发展环境友好的催化体系, 利用分子氧来实现醇的高效选择性氧化.

在过去的30年里, 金催化剂在多种气相和液相反应中的催化性能和反应机理已被深入研究. 近年来, 金催化剂在醇选 择性氧化反应中表现出高的催化活性和特殊的选择性. 设计和制备合适的载体对金催化剂取得优异的醇氧化催化活性有 至关重要的作用. 先前的研究工作报道氧化锌是一种碱性材料, 其表面没有酸性位. $\mathrm{Au} / \mathrm{ZnO}$ 催化剂在苯甲醇氧化反应中 表现出高的苯甲醛选择性和低的苯甲醇转化率. 在本研究工作中, 我们向 $\mathrm{ZnO}$ 载体中掺杂 $\mathrm{Cu}$ 元素, 制备出一系列 $\mathrm{ZnO}-\mathrm{CuO}$ 复合氧化物, 并进一步负载金用于催化苯甲醇氧化反应。研究结果表明, 在无碱的反应条件下, $\mathrm{Au} / \mathrm{ZnO}-\mathrm{CuO}$ 催化剂比 $\mathrm{Au} / \mathrm{ZnO}$ 和 $\mathrm{Au} / \mathrm{CuO}$ 催化剂具有更高的苯甲醇氧化催化活性, 其中 $\mathrm{Au} / \mathrm{Zn}_{0.7} \mathrm{Cu}_{0.3} \mathrm{O}$ 催化剂表现出最优的催化活性. 我们还研究 了反应温度和氧气压力对 $\mathrm{Au} / \mathrm{Zn}_{0.7} \mathrm{Cu}_{0.3} \mathrm{O}$ 催化苯甲醇选择性氧化活性的影响, 探索了 $\mathrm{Au} / \mathrm{Zn}_{0.7} \mathrm{Cu}_{0.3} \mathrm{O}$ 催化剂对多种醇氧化反 应的普遍适用性, 考察了 $\mathrm{Au} / \mathrm{Zn}_{0.7} \mathrm{Cu}_{0.3} \mathrm{O}$ 催化剂对醇氧化反应的催化循环性能. 我们发现 $\mathrm{Au} / \mathrm{Zn}_{0.7} \mathrm{Cu}_{0.3} \mathrm{O}$ 催化剂在无碱温和 的反应条件下可以将1-苯基乙醇、对甲基苯甲醇、对异丙基苯甲醇、二苯甲醇、环丙基苯甲醇和肉桂醇高效选择性氧化 为对应的羰基化合物, 但对正辛醇氧化反应表现出相对较低的催化活性. 此外, $\mathrm{Au} / \mathrm{Zn}_{0.7} \mathrm{Cu}_{0.3} \mathrm{O}$ 催化剂在苯甲醇氧化反应的 催化循环中容易失活, 而在1-苯基乙醇氧化反应的催化循环中则表现出较好的稳定性.

利用X射线衍射、氮气吸脱附、氢气程序升温还原、透射电子显微镜、二氧化碳程序升温脱附和氧气程序升温脱附等 方法对金催化剂的物化性质进行了表征, 并提出了金催化苯甲醇选择性氧化可能的反应机理. 我们认为 $\mathrm{Au} / \mathrm{Zn}_{0.7} \mathrm{Cu}_{0.3} \mathrm{O}$ 催 化剂优异的催化活性与其小的金粒径、好的低温还原性能、高的表面氧物种含量、表面酸碱性及金粒子与载体的协同效 应等密切相关.

关键词: 金催化; 锌铜复合氧化物; 醇; 有氧氧化; 无碱反应

收稿日期: 2019-04-29. 接受日期: 2019-06-23. 出版日期: 2019-12-05.

*通讯联系人. 电话: (0411)82463012; 传真: (0411)82463009; 电子信箱: jiahuihuang@dicp.ac.cn

\#通讯联系人. 电话: (0411)82463017; 传真: (0411)82463009; 电子信箱: yanxie@dicp.ac.cn

基金来源: 国家自然科学基金(21606219); 中国科学院战略性先导科技专项变革性洁净能源关键技术与示范(XDA21030900).

本文的电子版全文由Elsevier出版社在ScienceDirect上出版(http://www.sciencedirect.com/science/journal/18722067). 